\title{
Legislator Influence and Public School Finance
}

\section{Larry DeBoer, Kevin T. McNamara, John Cranfield, and Thea Graham*}

\begin{abstract}
We test several hypotheses about coalition forming in legislatures using data on Indiana school finance from the 1990s. School district state aid per pupil is regressed on district characteristics and political characteristics of each district's legislators. Results show no evidence of policy cycling. A new coalition appears to have formed in a year when a new party took power in the House. Smaller districts, and districts represented by new legislative leaders, appear to gain aid in new coalitions. There is evidence that legislators seek equalization, but perhaps only under threat of litigation.
\end{abstract}

\section{INTRODUCTION}

This study analyzes school finance decisions made by the Indiana state legislature from 1990 through 1996, to test several hypotheses about the formation of legislative coalitions to support particular funding distributions. The state's intent regarding school finance is expressed in the school aid formula. The amount of state aid delivered to each school district is taken as a measure of the results of this formula's design. We use data on school district and legislator characteristics to test hypotheses about policy cycling, agenda control, coalition formation, and equalization. School districts are called corporations in Indiana, but throughout this paper we use "district," which is the more common term.

\section{EDUCATION FINANCE IN INDIANA}

The state of Indiana operates on a two-year budget cycle, with the biennial budget passed in odd-numbered years. The General Assembly usually revises the school funding formula in budget years as part of the decision on the school aid appropriation. The formula distributes about $\$ 3$ billion in state aid among Indiana's 294 school districts, with the average district receiving about 60 percent of its budget from state sources. The rest of district budgets are financed primarily with property taxes.

The school formula is complex. Among the variables required to calculate state aid are various measures of current and previous year enrollment, current and previous year tax revenues, the property tax rate, and target spending levels and annual growth. The formula also includes measures of vocational education effort, special education requirements, academic honors programs, community poverty, single-parent families, and education levels (Indiana Department of Education 1999). Despite its complexity, at base it is a foundation formula, with per pupil aid calculated as target spending per pupil less local resources per pupil.

*DeBoer and McNamara are Professors, Department of Agricultural Economics, Purdue University, West Lafayette, Indiana. Cranfield is an Assistant Professor, Department of Agricultural Economics and Farm Management, University of Manitoba, Winnipeg, Manitoba. Graham is an Economist with the Bureau of Economic Analysis, Washington, D.C. 
Johnson and Lehnen (1993) provide a history of Indiana school finance. They cite several factors that have driven Indiana state school aid decisions since 1973. Legislators have tried to limit property taxes, they have tried to assure accountability by increasing the share of state aid funded through categorical grants, and they have tried to increase spending of the lowest spending districts. The legislature has been only partially successful in reaching these goals. In fact, Johnson and Lehnen (1993) argue that a mid-1980s formula revision designed to equalize spending actually created greater inequality. The range of spending per pupil between high- and low-spending districts increased in the late 1980 s by several standard measures. One reason is the legislature's unwillingness to limit spending growth by high-spending districts.

Johnson and Lehnen (1993) cite a fourth factor driving school funding decisions: "a sufficient number of school districts must receive benefits to garner enough legislative votes to enact a distribution formula" (p. 265). A majority coalition must be formed to support a particular distribution. Other writers on education finance have made this observation. Brown and Elmore (1982) write that policy makers look for a "politically feasible mix" of school finance objectives (p. 126) and that making finance policy is "constructing a package of side-payments sufficient to bind an increasingly divided education lobby together" (p. 127). Wong (1991) notes that "the legislative design for the distribution of state aid to education continues to mirror the distribution of power in the legislature" (p. 132).

\section{THEORY}

This paper investigates the political and economic factors that influence the formation of majority coalitions supporting a school funding formula. Suppose that each legislator attempts to maximize the net fiscal benefit that the school formula provides to school districts in his or her legislative district. Net fiscal benefit is the aid delivered to a legislator's district less taxes raised from the district. Legislators may be motivated by a positive relationship between net fiscal benefits and the probability of reelection, by the legislators' own taxes paid and services received, and by of a sense of responsibility to their constituents.

A large number of studies use the maximization of net fiscal benefit or similar ideas to model legislative behavior (Levitt and Snyder 1997). de Bartolome (1997) applies the idea to explain the determinants of state school aid. The empirical evidence has been mixed, but Levitt and Snyder (1997) show that increases in federal spending within House districts increase incumbents' share of votes in subsequent elections. Each added $\$ 100$ spending per capita increases votes received by 2 percent. Legislators can enhance their reelection prospects by delivering more spending to their districts. Suppose that to maximize net fiscal benefit legislators strive to be members of a majority coalition. The majority coalition votes to pass a policy that benefits coalition members more than nonmembers.

School funding is done by formula (Advisory Commission on Intergovernmental Relations 1990), and formulas are created by legislatures. Funding 
formulas cannot be so simple as to say explicitly that districts represented by majority coalition legislators receive more aid than those represented by others. Such formulas would probably not withstand court challenges (see below). Instead, school formulas distribute aid based on characteristics of districts, imbedded in particular functional forms. Characteristics often considered in a school formula are property wealth; current and past spending levels and tax rates; socioeconomic characteristics of districts and pupils; assessment equalization ratios; numbers of disabled, advanced, or vocational students; transportation pupil-miles; enrollment growth; test scores; and many others. Formulas could take the form of flat per pupil grants, or more complex forms such as foundation or power equalization formulas.

Probably relatively few legislators understand the workings of intricate school funding formula proposals. They may instead "vote the printout," that is, vote based on the formula's funding results for the school districts in their legislative districts. Staff analysts produce a computer printout showing the proposed aid levels for each school district in the state. A legislator votes for the formula if the printout shows that all or most of his or her school districts receive high aid levels or large percentage increases over the previous year. It is up to a would-be majority coalition "manager," then, to choose a formula with characteristics and a functional form that benefits enough school districts (including his or her own) to make a majority.

Majority-rule legislatures may exhibit "cycling." Cycling occurs when legislators outside a majority coalition, whose districts are excluded from a policy's benefits, try to form a new majority coalition with a policy favorable to their districts. They can accomplish this by enticing enough members out of the old coalition into a new majority coalition supporting a more favorable policy. New majority coalitions that rearrange winners and losers are always feasible, so the content and results of the funding formula may constantly shift from one legislative session to the next. Mueller $(1989,1996)$ provides reviews of the cycling literature.

Consider the example shown in Table 1, based on Stratmann (1996). There are three districts, each represented by one legislator, and three consecutive votes are taken. No cycling occurs in the first example. In each vote, districts 1 and 2 favor a school formula that gives each four-tenths of the total to be allocated, leaving two-tenths for district 3 (whose legislator votes against this allocation). Cycling occurs in the second example in Table 1. Vote 1 is the same as with no cycling, with districts 1 and 2 receiving four-tenths and district 3 two-tenths. In vote 2, however, districts 2 and 3 form a new coalition, which they both prefer to the first because their districts both receive more. District 1 is the losing voter. In vote 3 , districts 1 and 3 combine to increase their shares over vote 2 , with district 2 losing. Finally, the original vote is preferred over vote 3 by districts 1 and 2 .

A new majority coalition favoring a different allocation of aid is always possible. Two districts (a majority) prefer vote 2 to vote 1 , two districts prefer vote 3 to vote 2 , and two districts prefer vote 1 to vote 3 . This is the basis of the cycling 
argument. A majority of voters can always benefit by combining in a new coalition that reallocates resources, so in a majority-rule legislature formulas allocating resources would be in constant flux.

TABLE 1

Illustration of Cycling

\begin{tabular}{|c|c|c|c|c|c|}
\hline \multicolumn{6}{|l|}{ No Cycling } \\
\hline & & Vote 1 & Vote 2 & Vote 3 & Sum \\
\hline & District 1 & 0.4 & 0.4 & 0.4 & 1.2 \\
\hline & District 2 & 0.4 & 0.4 & 0.4 & 1.2 \\
\hline & District 3 & 0.2 & 0.2 & 0.2 & 0.6 \\
\hline Variance & & 0.009 & 0.009 & 0.009 & 0.080 \\
\hline Correlation & & $100 \%(w / 3)$ & $100 \%(w / 1)$ & $100 \%(w / 2)$ & \\
\hline \multicolumn{6}{|l|}{ Cycling } \\
\hline & & Vote 1 & Vote 2 & Vote 3 & Sum \\
\hline & District 1 & 0.4 & 0.2 & 0.3 & 0.9 \\
\hline & District 2 & 0.4 & 0.5 & 0.2 & 1.1 \\
\hline & District 3 & 0.2 & 0.3 & 0.5 & 1.0 \\
\hline Variance & & 0.009 & 0.016 & 0.016 & 0.007 \\
\hline Correlation & & $-94 \%(w / 3)$ & $19 \%(w / 1)$ & $-50 \%(w / 2)$ & \\
\hline
\end{tabular}

Table 1 also shows two tests for cycling. Stratmann's (1996) test compares the sum of the variances of the results of each vote to the variance of the sum of the results of all votes. Where there is no cycling, the sum of the variances will be less than the variance of the sum (here, $0.009+0.009+0.009=0.027$, less than 0.080 ). Where there is cycling, the sum of the variances will exceed the variance of the sum (here, $0.009+0.016+0.016=0.041$, greater than 0.007 ). Cycling also can be tested by correlations between the distributions in consecutive votes. If the correlation is near one, cycling does not occur, because the allocations are similar year to year. If the correlation is closer to zero or negative, cycling is indicated, because the allocations change year to year, with at least some losers becoming winners and some winners becoming losers.

If cycling was pervasive, formulas passed in consecutive sessions might bear little relation to one another. Legislators outside the coalition in one year would try to fashion a new majority coalition in the next, and sometimes they would succeed. The formula's characteristics, functional form, and printout aid distribution could change significantly in each legislative session.

Stratmann (1996) found no evidence of cycling when he applied his test to the U.S. Congress. That cycling is not pervasive has been the general finding of literature testing for cycling (Mueller 1989). Several reasons may be offered for why cycling may not occur in school finance decisions. One way around cycling is to have someone set an agenda. Baron and Ferejohn (1987) propose a model in which a member of a three-person legislature is recognized at random to make a proposal. If no amendments are allowed, it is always possible for this recognized member to propose a distribution that will achieve a majority. Each member knows that the expected value of his or her share over all possible proposed dis- 
tributions is one-third of the total, so the recognized member simply proposes a distribution giving a little less than two-thirds to his or her district and a little more than one-third to another member's district (and none to the remaining member). The proposal gains a majority and the legislature goes home. The result is weaker if amendments are allowed.

The main point remains: the member who sets the agenda is likely to receive a disproportionate share of the distribution. In most legislatures these agenda setters are not randomly chosen, and they tend to remain in place year after year. Possible agenda setters for the school aid formula include legislative leaders, committee chairs, experienced legislators, important committee members, and members of important committees. Legislators with the power to set agendas will likely succeed gaining a disproportionate share of the net fiscal benefits for their own districts. School districts in the legislative districts of legislative leaders and committee heads should do better than districts that are represented by legislators with no power over the agenda.

Another way around the cycling problem is through party discipline. Cycling requires that legislators be free to switch sides when those outside the majority coalition make a better offer. But if the majority coalition is formed by the majority party, and the party can enforce penalties for joining in a coalition with the minority party, the cycling problem may be eliminated. No offer by the minority, no matter how attractive, may induce a majority party member to support the minority's policy if he or she fears the party's retribution. The majority party coalition would design a formula that maximizes the net fiscal benefits of the school districts they represent. Alternate formulas would be rejected by all majority party members, even if the alternatives benefit some members' districts. This implies that school districts represented by members of the majority party should do better than those represented by minority party members.

Both the Indiana Senate and House are equally apportioned according to population. There are several reasons to think that they are not equally apportioned according to public school enrollment, however. First, some districts may have more children as a proportion of the population, some less. School districts in which children are scarce will be relatively overrepresented in the legislature. Second, the amount of private school enrollment varies by district. Districts with much private school enrollment are overrepresented in the legislature. Third, since school district boundaries and legislative district boundaries are not the same, school districts of equal enrollment may be represented by differing numbers of legislators. One school district may be entirely within a legislator's district, while another may straddle two legislators' districts. Two legislators will attend to the latter district's fortunes when they "vote the printout."

Some legislators represent more public school children, some less. Legislators try to belong to the majority coalition, which delivers more aid per pupil to its members' districts than to those outside the coalition. If the representative of a district with a large number of public school children is added to the coalition, 
more tax revenue must be raised. Every legislator's net fiscal benefit is likely to be reduced. A legislator representing a district with fewer public school children adds the same one vote to the coalition, but at a smaller tax cost. The net fiscal benefit for the winning coalition is greater if the legislators in the coalition represent a smaller number of public school children. The winners obtain the same added aid, but the tax costs to all districts are smaller. Snyder (1993) formalizes this argument, with legislators competing to join a majority coalition by reducing the size of the projects they hope to fund.

The implication of unequal representation for school aid distribution is that districts represented by more legislators, and districts with smaller enrollments, are more likely to receive greater net fiscal benefits. In a sense, a district's enrollment per legislator is a measure of its cost to be included in the majority coalition. Lower-cost districts are favored. An analysis of the U.S. Senate by Atlas et al. (1995) provides evidence that nonproportional representation affects the distribution of spending. Small states have greater per capita representation in the Senate, since each state has two senators regardless of population. The authors find that over the 1972-90 period, per capita federal spending was greater in smaller states.

Legislators who represent more than one school district may have a problem when the interests of their districts do not coincide. A legislator may represent both a rich and a poor district, or a large-enrollment and a small-enrollment district. Any formula's printout may show some of the legislator's districts winning, others losing. Whether this problem is enough to negate the effects of unequal representation is an empirical question.

Self-interest may motivate legislators, but other factors may also be at work. A primary goal of school funding formulas in the past several decades has been funding equity, meaning the equalization of funding per pupil across school districts. This has been one of several school funding goals for the Indiana legislature as well, though the extent to which this goal has been achieved is questionable (Johnson and Lehnen 1993). Still, the ideal of fairness may exert an influence over legislators that may at least partially overcome self-interest. Legislators may support a formula that does not maximize their districts' net fiscal benefits if they are persuaded that the public interest is served by equalization.

Under some conditions equalization may emerge as legislators pursue their own interests. There may be no need to assume legislator altruism. Suppose some districts are rich, others are poor. Sales and income taxes are proportional to income, so the rich pay more taxes, and the poor pay less. Suppose legislators can vote between two aid plans, one that returns the districts' state tax payments back in aid (or collects no state taxes and distributes no state aid), and another that gives each district an equal share of state tax collections. The former plan involves no equalization; the latter equalizes by redistributing tax revenue from rich to poor districts. Self-interested legislators vote for the plan that maximizes their districts' net fiscal benefits (aid less tax payments). If the median tax payment is less 
than the average tax payment, the equalizing plan will pass. If the median tax payment is greater than the average tax payment, the nonequalizing plan will pass. This occurs because the median legislator is decisive under these conditions. If the median tax payment is less than the average tax payment, the median district receives more in aid than it pays in taxes when tax revenue is equally distributed. The median district's representative votes for the equalizing aid plan, and this plan gets a majority of the vote. Put another way, if the majority of districts are poorer than average, their representatives will vote to redistribute resources from the rich. This argument is illustrated in Table 2.

TABLE 2

Income Inequality and Equalization

\begin{tabular}{lcccccc}
\hline & \multicolumn{3}{c}{$\begin{array}{c}\text { Median Tax Payment } \\
\text { Less than Average }\end{array}$} & \multicolumn{3}{c}{$\begin{array}{c}\text { Median Tax Payment } \\
\text { Greater than Average }\end{array}$} \\
\hline District & $\begin{array}{c}\text { Tax } \\
\text { Payments }\end{array}$ & $\begin{array}{c}\text { Equal Aid } \\
\text { Distribution }\end{array}$ & Vote & $\begin{array}{c}\text { Tax } \\
\text { Payments }\end{array}$ & $\begin{array}{c}\text { Equal Aid } \\
\text { Distribution }\end{array}$ & Vote \\
\hline Rich & 0.7 & 0.333 & No & 0.5 & 0.333 & No \\
Median & 0.2 & 0.333 & Yes & 0.4 & 0.333 & No \\
Poor & 0.1 & 0.333 & Yes & 0.1 & 0.333 & Yes \\
\hline
\end{tabular}

Meltzer and Richard (1981) use this argument to demonstrate why rational, self-interested legislatures support redistribution. They argue that the redistributive efforts of government, and therefore government spending levels, increase when average income exceeds the median. de Bartolome (1997) applies this argument to explain why state school aid has increased in recent decades. The distribution of income in the United States has become less equal, so that average income has exceeded median income by even greater amounts. The incentive to equalize has become greater. de Bartolome finds that between one-third and twothirds of the increase in state aid between 1970 and 1990 is due to increasing income inequality.

A second argument shows that equalization may be in legislators' selfinterests, even if their own districts are not direct beneficiaries of equalization. Citizens have gone to court seeking greater equality in per pupil funding across districts. Sometimes state courts have interpreted their constitutions as requiring equalization. Evans, Murray, and Schwab (1997) list 43 states with court challenges to school funding systems between 1970 and 1993, and 16 where funding systems have been overturned. They also find that in-state school funding inequality has decreased in states with court-ordered reform, compared to other states. A court case challenging funding inequality was filed in Indiana in 1987, but it was dropped after reforms in the school aid formula in 1993 (Johnson 1993).

If legislators perceive the threat of a court challenge to the formula, they may be motivated by self-interest to support some equalization. Dougan and Snyder (1996) note that if legislators are risk averse, they may prefer a known distribution to an unknown new distribution under which their districts may win or lose. Since successful court challenges cause big changes in aid formulas (Evans, 
Murray, and Schwab 1997), risk-averse legislators may support just enough equalization to head off a court case, or enough to provide evidence in court that the system is equalizing. Fuhrman (1982) found that legislators sometimes initiate reform for fear of a court case, even in states where no suits were filed.

Several hypotheses are implied by these ideas. Majority-rule legislatures may be subject to cycling. If cycling is not pervasive, each year's school funding distribution should be positively correlated with the previous year's distribution. If cycling is pervasive, the previous year's distribution will not be positively correlated with current year funding. Legislative leaders may have the power to set agendas, and so influence funding results. If so, they will protect their own districts' interests. Districts represented by legislative leaders should receive more aid per pupil, all else equal. Party discipline may prevent cycling, allowing the majority party to form a stable coalition. Districts represented by members of the majority party should receive more aid. Unequal representation implies that it is less costly to form a majority that includes districts with smaller enrollments and more representatives. All else equal, school districts with smaller enrollments and more legislators should receive more aid per pupil. Finally, either because of ideas of fairness, or because the median legislator benefits from redistribution, or to head off court cases that could cause coalition-disrupting reforms, the majority coalition may support equalization. Over time, lower-income school districts should receive bigger per pupil aid increases, all else equal.

\section{EMPIRICAL MODEL AND DATA}

The hypotheses about cycling, agenda setting, unequal representation, and equalization are tested using data for Indiana public schools for the years 1988 through 1996. School data were obtained from the Indiana Department of Education. Data on the Indiana Legislature were provided by the Indiana Legislative Services Agency and various issues of the State of Indiana Index to House and Senate Journals. The units of observation are the individual school districts, called school corporations in Indiana. The dependent variable is total state aid to school districts per pupil in 1990, 1992, 1994, and 1996.

The Indiana school funding formula is decided upon only once in each biennial legislative term, in the "long" session in odd-numbered years. The state budgets on a July through June fiscal year, while school districts budget on a calendar year. Thus, state aid in odd-numbered calendar years reflects a formula agreed upon by legislators in the former and current legislatures. State aid in the first six months of odd-numbered years reflects the formula determined two years previous, while aid in the second six months reflects the formula determined in the current year. State aid in even-numbered years, however, represents the results of only one formula, passed by legislators in the previous odd-numbered year. The best measure of legislator intent for school support levels, then, is aid in evennumbered years. To determine the effect of legislator and school district characteristics on the level of support received, current period support in evennumbered years is regressed on characteristics in the previous, odd, year. 
The model is expressed as:

$$
\text { LSA }_{\mathrm{it}}=\mathrm{f}\left(\begin{array}{l}
\text { LSA }_{\mathrm{it}-2}, \text { INDEXS }_{\mathrm{it}-1}, \text { INDEXH }_{\mathrm{it}-1}, \text { REPUBLICANS }_{\mathrm{it}-1}, \\
\text { REPUBLICANH }_{\mathrm{it}-1}, \text { YEARS }_{\mathrm{it}-1}, \text { YEARH }_{\mathrm{it}-1}, \text { NEWS }_{\mathrm{it}-1} \\
\text { NEWH }_{\mathrm{it}-1}, \text { LTOTALH }_{\mathrm{it}-1}, \text { LADM }_{\mathrm{it}-1}, \text { LINCOME }_{\mathrm{i} 87}
\end{array}\right),
$$

where $\mathrm{LSA}_{\mathrm{it}}$ is the $\log$ of the per pupil ${ }^{1}$ state aid, $\mathrm{i}$ is an index of school districts, and $t$ is a time index. Since the composition of legislators in the House and Senate typically changes with each election, Equation 1 is specified for four different years. These years coincide with state funding received by the ith school district in 1990, 1992, 1994, and 1996. For reference Table 3 shows summary statistics for the dependent and explantory variables.

TABLE 3

Dependent and Explanatory Variable Summary Statistics

\begin{tabular}{|c|c|c|c|c|c|c|c|c|}
\hline VARIABLE & MEAN & STD & MIN & MAX & MEAN & STD & MIN & MAX \\
\hline & \multicolumn{4}{|c|}{1990} & \multicolumn{4}{|c|}{1992} \\
\hline$\overline{\mathrm{LSA}_{\mathrm{t}}}$ & 7.52 & 0.29 & 5.55 & 8.95 & 7.64 & 0.29 & 5.17 & 8.12 \\
\hline $\mathrm{LSA}_{\mathrm{t}-2}$ & 7.35 & 0.33 & 3.97 & 8.32 & 7.52 & 0.29 & 5.55 & 8.95 \\
\hline INDEXS $_{t-1}$ & 1.55 & 1.51 & 0.00 & 14.00 & 1.62 & 1.24 & 0.00 & 11.00 \\
\hline INDEXH $_{t-1}$ & 2.06 & 1.24 & 0.00 & 11.00 & 1.40 & 1.01 & 0.00 & 7.00 \\
\hline REPUBLICANS $_{\mathrm{t}-1}$ & 0.56 & 0.48 & 0.00 & 1.00 & 0.56 & 0.48 & 0.00 & 1.00 \\
\hline REPUBLICANH $_{t-1}$ & 0.52 & 0.46 & 0.00 & 1.00 & 0.51 & 0.46 & 0.00 & 1.00 \\
\hline YEARS $_{t-1}$ & 9.22 & 9.83 & 0.00 & 91.00 & 11.11 & 10.28 & 0.00 & 89.00 \\
\hline $\mathrm{YEARH}_{\mathrm{t} 1}$ & 17.49 & 16.21 & 0.00 & 158.00 & 16.23 & 17.00 & 0.00 & 172.00 \\
\hline NEWS $_{t-1}$ & 0.28 & 0.46 & 0.00 & 2.00 & 0.04 & 0.24 & 0.00 & 2.00 \\
\hline $\mathrm{NEWH}_{t-1}$ & 0.15 & 0.38 & 0.00 & 2.00 & 0.36 & 0.57 & 0.00 & 2.00 \\
\hline LTOTALH $_{t-1}$ & -7.32 & 0.76 & -9.65 & -5.32 & -7.32 & 0.76 & -9.65 & -5.32 \\
\hline $\mathrm{LADM}_{\mathrm{t}-1}$ & 7.64 & 0.83 & 5.43 & 10.90 & 7.64 & 0.83 & 5.41 & 10.86 \\
\hline $\mathrm{LAV}_{\mathrm{t} 1-}$ & 10.22 & 0.40 & 8.75 & 11.76 & 10.51 & 0.38 & 9.10 & 11.89 \\
\hline \multirow[t]{2}{*}{ LINCOME $_{i 87}$} & 9.25 & 0.16 & 8.88 & 9.95 & & & & \\
\hline & \multicolumn{4}{|c|}{1994} & \multicolumn{4}{|c|}{1996} \\
\hline$\overline{\mathrm{LSA}_{\mathrm{t}-1}}$ & 7.78 & 0.29 & 4.99 & 8.27 & 7.86 & 0.38 & 5.49 & 10.22 \\
\hline $\mathrm{LSA}_{+2}$ & 7.64 & 0.29 & 5.17 & 8.12 & 7.78 & 0.29 & 4.99 & 8.27 \\
\hline INDEXS $_{t-1}$ & 2.37 & 1.64 & 0.00 & 10.00 & 2.34 & 1.57 & 0.00 & 9.00 \\
\hline INDEXH $_{t-1}$ & 1.69 & 1.47 & 0.00 & 13.00 & 1.48 & 1.28 & 0.00 & 12.00 \\
\hline REPUBLICANS $_{t-1}$ & 0.56 & 0.46 & 0.00 & 1.00 & 0.64 & 0.44 & 0.00 & 1.00 \\
\hline REPUBLICANH & 0.44 & 0.44 & 0.00 & 1.00 & 0.58 & 0.44 & 0.00 & 1.00 \\
\hline YEARS $_{t-1}$ & 13.32 & 10.75 & 0.00 & 69.00 & 15.40 & 11.66 & 0.00 & 75.00 \\
\hline YEARH $_{t-1}$ & 13.34 & 13.73 & 0.00 & 91.00 & 13.05 & 14.20 & 0.00 & 87.00 \\
\hline $\mathrm{NEWS}_{t-1}$ & 0.12 & 0.37 & 0.00 & 2.00 & 0.07 & 0.25 & 0.00 & 1.00 \\
\hline $\mathrm{NEWH}_{\mathrm{t}-1}$ & 0.37 & 0.61 & 0.00 & 4.00 & 0.26 & 0.49 & 0.00 & 3.00 \\
\hline LTOTALH $_{\text {t-1 }}$ & -7.23 & 0.7 & -8.87 & -5.36 & -7.23 & 0.70 & -8.87 & -5.36 \\
\hline LADM $_{t-1}$ & 7.65 & 0.83 & 5.43 & 10.83 & 7.66 & 0.83 & 5.44 & 10.80 \\
\hline $\mathrm{LAV}_{\mathrm{t}-1}$ & 10.53 & 0.81 & 6.88 & 13.45 & 10.57 & 0.81 & 6.92 & 13.57 \\
\hline
\end{tabular}

Since legislative districts do not follow school district boundaries, each school district is assumed to be represented by all legislators whose districts overlap the district's boundaries. Thus, characteristics of legislators in the ith school district reflect an aggregate of all senators and representatives whose districts overlap that school district.

${ }^{1}$ State aid in period $t$ was divided by the number of pupils in the ith school district in period $t-1$. This was done to relate the level of state aid to characteristics of the ith district known to legislators in the year the formula decision was made (i.e., the number of pupils in a district in $t-1$ ). 
$\mathrm{LSA}_{\mathrm{it}-2}$ is $\mathrm{LSA}_{\mathrm{it}}$ lagged two periods, and is included to measure the degree to which the previous funding formula influences the current funding formula. If the coefficient on this variable is positive and significant, policy cycling is not pervasive. However, if this coefficient is not positive, or is insignificant, then cycling may be present.

INDEXS $_{\text {it- } 1}$ is a measure of leadership and committee positions held by senators in the ith school district, and $\mathrm{INDEXH}_{\mathrm{it}-1}$ is a similar measure for representatives. Leadership positions are defined to be Speaker of the House and the President Pro Tempore in the Senate. A committee position is defined to include Chair, Vice-Chair, Ranking Member, or Ranking Minority Member of any Senate or House committee. Also included are all members of the House Ways and Means Committee and Senate Finance Committee. These committees are especially influential in writing the formula in Indiana. Fuhrman (1982) notes that appropriations committees have been gaining power over the school formula at the expense of education committees. The index value equals the sum of the number of leadership and committee service positions held by legislators whose districts overlap the ith school district. Coefficients on INDEXS it- $1_{1}$ and INDEXH $\mathrm{I}_{\mathrm{it}-1}$ are expected to be positive since legislators serving in leadership or important committee roles are more likely to be agenda setters. They may influence the sequence and outcome of votes to favor a formula that provides a higher level of support for school districts they represent.

REPUBLICANS $_{\mathrm{it}-1}$ measures the percent of the Senate districts overlapping the ith school district held by Republicans, while REPUBLICANH $\mathrm{it}_{\mathrm{it}-1}$ measures the same for House districts held by Republicans. When Republicans are in the majority-in all four years in the Senate, and in 1995-1996 in the House--coefficients on these variables should be positive. If majority coalitions form along party lines, and are maintained through party discipline, school districts represented by members of the majority party would be expected to receive more state aid.

YEARS $_{i t-1}$ and $Y E A R H_{i t-1}$ measure total legislative service by senators and representatives, respectively, in the ith school district. Presumably, veteran legislators are more likely to be agenda setters, or are more adept at keeping themselves in coalitions. Either way, school districts with experienced legislators are expected to receive more state aid. Consequently, the coefficients on these variables are expected to be positive.

$\mathrm{NEWS}_{\mathrm{it}-1}$ and $\mathrm{NEWH}_{\mathrm{it}-1}$ are the total number of new legislators from the Senate and House, respectively, representing the ith school district. These variables account for the influence of including inexperienced legislators in a coalition. The coefficient signs could be positive or negative. New legislators may be prime candidates for inclusion in new coalitions, to the benefit of the school districts they represent. Or, inexperienced new members may be inept at the coalition game, to the detriment of their school districts.

LTOTALH $_{\mathrm{it}-1}$ is the log of the per pupil number of House representatives in the ith school and LADM $\mathrm{it}_{-1}$ is the log of average daily membership in the ith 
school district. ${ }^{2}$ Both LTOTALH ${ }_{\mathrm{it}-1}$ and $\mathrm{LADM}_{\mathrm{it}-1}$ are included to test the unequal representation hypothesis. Majority coalitions may favor school districts with smaller enrollments relative to the number of representatives in that district; that is, a larger legislator/enrollment ratio, or a smaller total enrollment. The smaller is enrollment and the larger is the number of representatives, the larger should be the level of state aid received. If the unequal representation hypothesis is consistent with the evidence, the coefficient on LTOTALH $\mathrm{H}_{\mathrm{it}-1}$ is expected to be positive, while the coefficient on $L A D M_{i t-1}$ is expected to be negative.

LINCOME $_{\mathrm{i} 87}$ is the log of per capita income in the ith school district tabulated for 1987. Such income figures were not tabulated for any other year. Providing added support to lower-income school districts may be consistent with legislator self-interest or may be supported on equity grounds or to forestall court challenges. If a formula advances equalization, low-income school districts should receive a higher level of state aid. In such a case, the coefficient on $\mathrm{LINCOME}_{\mathrm{i} 87}$ is expected to be negative.

Since LINCOME $\mathrm{i}_{\mathrm{i87}}$ is an increasingly out-of-date measure of income, another model was specified that uses the log of per pupil assessed property values in the ith school district, $\mathrm{LAV}_{\mathrm{it}-1}$, instead of income. Assessed value is the county assessor's measure of the taxable wealth in each school district. Again, if a particular formula advances equalization, the coefficient on this variable is expected to be negative. The regressions using $\mathrm{LINCOME}_{\mathrm{i} 87}$ are referred to as income regressions, while those using $\mathrm{LAV}_{\mathrm{it}-1}$ are referred to as assessed value regressions. Again, descriptive statistics for data used in the analysis, by year, are presented in Table 3. Condition numbers were computed to test for multicollinearity (Kmenta 1986, p. 439). As no condition number was greater than 30 , multicollinearity was assumed not to be a problem.

\section{INDIANA POLITICS}

The political conditions in each legislative session are relevant for the interpretation of the hypotheses and the tests. In each of the four sessions, the Governor was a Democrat (Evan Bayh), and the Indiana Senate was controlled by Republicans by a strong majority. However, in 1989 (when the legislature wrote the 1990 formula) the Indiana House was tied 50-50 between Democrats and Republicans, the first time in Indiana history such a tie had happened (oddly, it happened again in 1997). Power was shared by joint "stereo" Speakers and each committee had alternating chairs. In 1991 and 1993 the Democrats held the majority in the House. Republicans regained the majority in 1995. In addition, legislative districts were redrawn for the 1993 legislature as a result of the 1990 Census. Thus, in the House, external factors probably increased the potential for new coalitions in 1991, 1993, and 1995. In 1991 and 1995 a new party was in the majority. In 1993, legislative districts were rearranged, changing the identity and number of legislators representing some school districts.

${ }^{2} \mathrm{~A}$ measure of the number of senators in a school district was not included since most school districts overlap only one Senate district. Including such a measure contributed inconsequential explanatory power to the regression, so the variable was not included. 
Other factors were at work, too. A court case filed by over 50 Indiana school districts, Lake Central School Corporation v. State of Indiana, in 1987 sought to overturn the funding formula because of per pupil spending inequity. The case was dropped in 1993 when the legislature adopted what appeared to be a major change in the school formula. Finally, in 1995 the Republican-controlled House Ways and Means Committee failed to pass a school formula for the first time in memory. The failure was attributed to inexperience on the part of Republican committee leaders, and to funding restrictions imposed by a balanced budget provision in the party's "Contract with Indiana." The Republican Senate wrote the formula instead.

The political situation strengthens the test of the hypotheses. The 1990 Census rearranged districts, meaning two sets of school-legislator links are present. Some school districts in a disadvantaged position in the first two sessions may have been advantaged in the last two due to changes in legislative district lines. A court case threatened the formula. If legislators support equalization based on self-interest, this pressure should have been especially great in the early 1990s, and lessened or eliminated in 1995. The House was at times controlled by Democrats, at times by Republicans and, in one year, by neither party. If being represented by legislative leaders or majority party members is important for school funding, most Indiana districts will have been in a favorable position at some time during this period.

\section{RESULTS}

The regression Equation 1 is specified for each year considered, with each school district treated as a cross-sectional unit. Initial estimates are obtained via Ordinary Least Squares, and the null hypothesis of homoskedastic errors tested using White's test. If this null hypothesis is rejected, the offending equation is then reestimated using a Maximum Likelihood framework to correct for heteroskedasticity.

Table 4 shows regression results for the 1990 and 1992 regressions, while Table 5 shows the same for the 1994 and 1996 regressions. Results from White's test suggested that both equations in the 1990 and 1996 samples had error terms consistent with homoskedastic errors at 5\% probability level. Results from the 1992 and 1994 regressions were consistent with heteroskedastic error terms. Consequently, regressions for the 1992 and 1994 samples were estimated using a Maximum Likelihood Estimator, which corrects for heteroskedasticity. An additional coefficient, the $\alpha$-value, is reported for the heteroskedastic-corrected regressions. This coefficient can be thought of as the standard deviation of the ratio of the residuals to $X$, where $X$ is the matrix of explanatory variables, and is a vector of coefficients.

Results from both 1990 regressions had adjusted $R^{2}$ values greater than 0.80 , and F-statistics consistent with rejection of the null hypothesis of joint zero coefficients at the $1 \%$ confidence level. For the 1992 sample, a simple correlation 
between actual and predicted values was used to measure how well the regression fit the data. In both 1992 regressions, this correlation coefficient was greater than 0.85 , while a Likelihood Ratio Test (LRT) indicated rejection of the null hypothesis of joint zero coefficients at the $1 \%$ confidence level.

\section{TABLE 4}

Regression Results - 1990 and 1992

\begin{tabular}{|c|c|c|c|c|}
\hline \multirow{3}{*}{ VARIABLE } & \multicolumn{2}{|c|}{1990} & \multicolumn{2}{|c|}{1992} \\
\hline & & ASSESSED & & ASSESSED \\
\hline & INCOME & VALUE & INCOME & VALUE $\ddagger$ \\
\hline \multirow{2}{*}{ CONSTANT } & $2.8935^{* * *}$ & $4.7335^{* * *}$ & $2.0092^{* * *}$ & $2.9577^{* * *}$ \\
\hline & 0.5266 & 0.4062 & 0.5290 & 0.4735 \\
\hline \multirow[t]{2}{*}{$\mathrm{LSA}_{\mathrm{it}-2}$} & $0.7836^{* * *}$ & $0.6432^{* * *}$ & $0.9400^{* * *}$ & $0.8315^{* * *}$ \\
\hline & 0.0217 & 0.0277 & 0.0224 & 0.0312 \\
\hline \multirow[t]{2}{*}{ INDEXS $_{\text {it-1 }}$} & 0.0055 & 0.0013 & $0.0166^{*}$ & 0.0096 \\
\hline & 0.0090 & 0.0082 & 0.0093 & 0.0091 \\
\hline \multirow{2}{*}{ INDEXH $_{\mathrm{it}-1}$} & -0.0129 & -0.0076 & $0.0294^{* * *}$ & $0.0324^{* * *}$ \\
\hline & 0.0108 & 0.0098 & 0.0104 & 0.0100 \\
\hline \multirow[t]{2}{*}{ REPUBLICANS $_{\mathrm{it}-1}$} & -0.0082 & -0.0163 & -0.0050 & -0.0099 \\
\hline & 0.0171 & 0.0156 & 0.0173 & 0.0166 \\
\hline \multirow{2}{*}{ REPUBLICANH $_{\mathrm{it}-1}$} & 0.0125 & 0.0164 & 0.0114 & 0.0128 \\
\hline & 0.0177 & 0.0157 & 0.0179 & 0.0171 \\
\hline \multirow{2}{*}{ YEARS $_{\mathrm{it}-1}$} & -0.0006 & 0.0003 & $-0.0019^{*}$ & -0.0009 \\
\hline & 0.0014 & 0.0012 & 0.0011 & 0.0011 \\
\hline \multirow[t]{2}{*}{ YEARH $_{\mathrm{it}-1}$} & 0.0002 & -0.0002 & 0.0003 & 0.0001 \\
\hline & 0.0007 & 0.0006 & 0.0006 & 0.0006 \\
\hline \multirow[t]{2}{*}{$\mathrm{NEWS}_{\mathrm{it}-1}$} & -0.0045 & -0.0048 & -0.0087 & -0.0125 \\
\hline & 0.0181 & 0.0166 & 0.0346 & 0.0335 \\
\hline \multirow{2}{*}{$\mathrm{NEWH}_{\mathrm{it}-1}$} & 0.0013 & 0.0094 & 0.0177 & 0.0151 \\
\hline & 0.0218 & 0.0200 & 0.0135 & 0.0130 \\
\hline \multirow{2}{*}{ LTOTALH $_{\mathrm{it}-1}$} & 0.0292 & 0.0334 & $-0.0492^{*}$ & -0.0417 \\
\hline & 0.0316 & 0.0290 & 0.0272 & 0.0263 \\
\hline \multirow[t]{2}{*}{ LADM $_{\mathrm{it}-1}$} & 0.0126 & 0.0116 & $-0.0607^{* *}$ & $-0.0584^{* *}$ \\
\hline & 0.0326 & 0.0297 & 0.0282 & 0.0272 \\
\hline \multirow[t]{2}{*}{ LINCOME $_{\mathrm{i} 87}$} & $-0.1079^{* * *}$ & & $-0.1502^{* * *}$ & \\
\hline & 0.0530 & & 0.0519 & \\
\hline \multirow[t]{2}{*}{$\mathrm{LAV}_{\mathrm{it}-1}$} & & $-0.1734^{* * *}$ & & $-0.1412^{* * *}$ \\
\hline & & 0.0228 & & 0.0261 \\
\hline \multirow[t]{2}{*}{$\alpha$-value } & & & $0.0152^{* * *}$ & $0.0147^{* * *}$ \\
\hline & & & 0.0006 & 0.0006 \\
\hline Adjusted $\mathrm{R}^{2}$ & 0.832 & 0.859 & $0.857^{\dagger}$ & $0.871^{\dagger}$ \\
\hline F-statistic & 115.307 & 141.720 & & \\
\hline Log of the Likelihood & 216.951 & 242.346 & 213.349 & 223.001 \\
\hline Likelihood Ratio Stat. & & & 536.056 & 555.360 \\
\hline White's test & 10.698 & 9.672 & 20.105 & 26.052 \\
\hline
\end{tabular}

\footnotetext{
Standard errors shown below the coefficients.

†Maximum likelihood estimate.

TSimple correlation between actual and predicted values.

*** Significantly different from zero at $\alpha=0.01$.

**Significantly different from zero at $\alpha=0.05$.

*Significantly different from zero at $\alpha=0.10$.
}

Results from both 1990 regressions had adjusted $R^{2}$ values greater than 0.80 , and F-statistics consistent with rejection of the null hypotheses of joint zero coefficients at the $1 \%$ confidence level. For the 1992 sample, a simple correlation between actual and predicted values was used to measure how well the regression 
fit the data. In both 1992 regressions, this correlation coefficient was greater than 0.85, while a Likelihood Ratio Test (LRT) indicated rejection of the null hypotheses of joint zero coefficients at the $1 \%$ confidence level.

\section{TABLE5}

Regression Results - 1994 and 1996

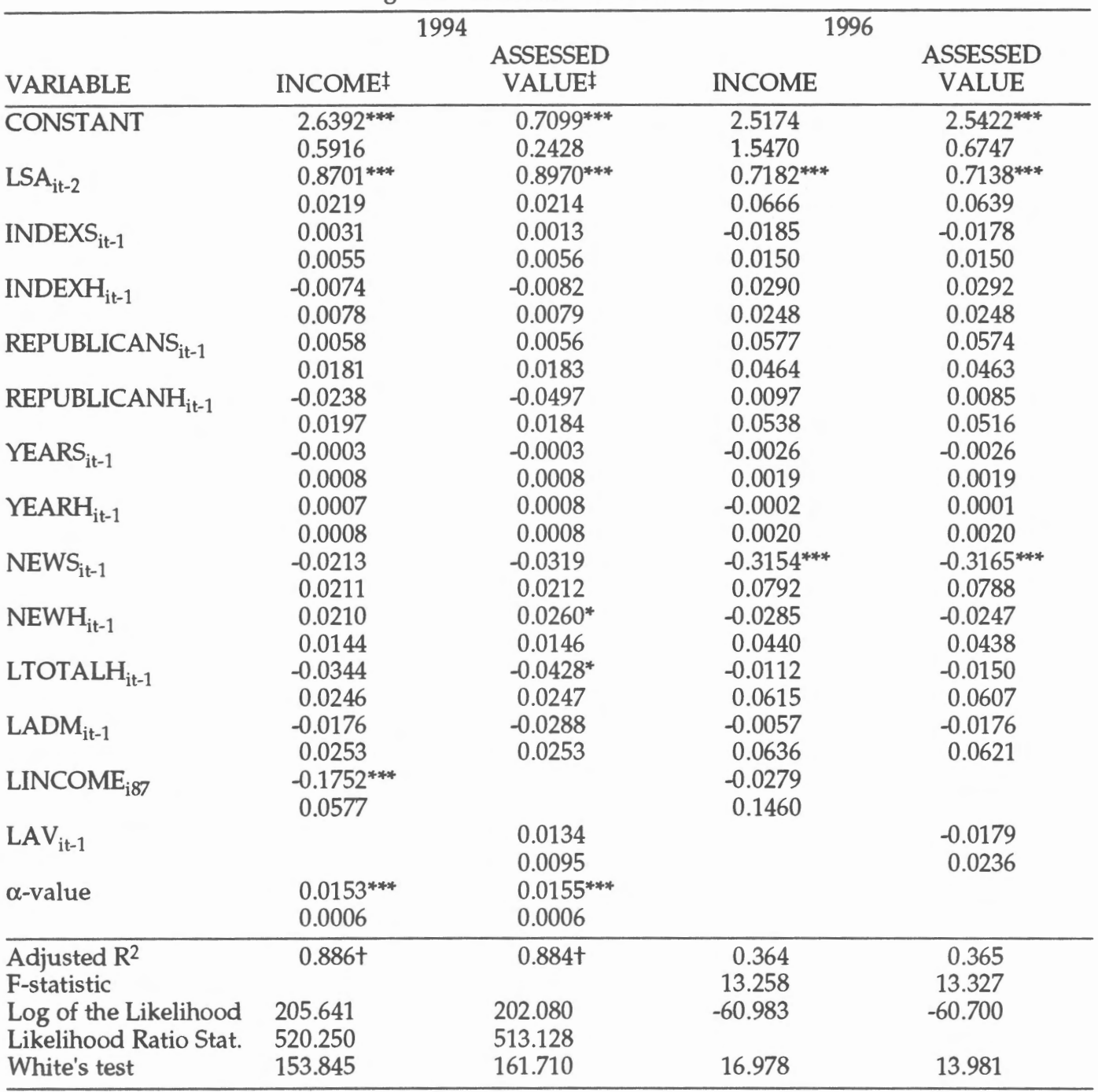

Standard errors shown below the coefficients.

† Maximum likelihood estimate.

${ }^{\dagger}$ Simple correlation between actual and predicted values.

$* * *$ Significantly different from zero at $\alpha=0.01$.

**Significantly different from zero at $\alpha=0.05$.

*Significantly different from zero at $\alpha=0.10$.

In both 1994 regressions, the correlation coefficient between actual and predicted state aid was greater than 0.85. An LRT indicated rejection of the null hypotheses of joint zero coefficient values at $1 \%$. However, 1996 regression results had low adjusted $\mathrm{R}^{2}$ values (both were below 0.40 ), although null hypotheses of joint zero coefficient values were rejected at the $5 \%$ confidence level. 
Results for the two tests for cycling described above are reported in Table 6. The 1988 school funding year was included to see if cycling occurred over the successive years analyzed. The first test compares the sum of the variance for each year (0.154) to the variance of the sums (0.751) (Stratmann 1996). Since the sum of the variance for each year is less than the variance of the sums, we conclude that cycling was not pervasive across the time period considered (see the example in Table 1). The other test examines the correlation between distributions of district shares in aid in consecutive votes (years). The correlations range from 0.99 between 1988 and 1990 to 0.912 between 1994 and 1996. These positive, large correlation coefficients also suggest cycling was not pervasive during the 1990-1996 period.

\section{TABLE 6}

Cycling Test Results

\begin{tabular}{lccccccc}
\hline & 1988 & 1990 & 1992 & 1994 & 1996 & $\begin{array}{c}\text { Sum of } \\
\text { Variance }\end{array}$ & $\begin{array}{c}\text { Variance } \\
\text { of Sums }\end{array}$ \\
\hline Variance $^{\mathrm{a}}$ & 0.033 & 0.032 & 0.031 & 0.029 & 0.029 & 0.154 & 0.751 \\
Correlation $^{\mathrm{b}}$ & & 0.999 & 0.998 & 0.998 & 0.912 & & \\
\hline
\end{tabular}

avariance reported in $10^{-3}$ units.

${ }^{b}$ Reported correlation coefficients measure correlation between current and previous year.

Recall that the lagged state aid variable $\left(\mathrm{LSA}_{\mathrm{it}-2}\right)$ was included to test whether policy cycling was pervasive in the school funding formula decision. In all regressions, the coefficient on lagged state aid was positive and significantly different from zero at $1 \%$. Thus, policy cycling does not appear to have been a pervasive influence on the level of funding received.

Results were mixed for the agenda-setting variables. These variables included the leadership index $\left(\mathrm{INDEXH}_{\mathrm{it}-1}, \mathrm{INDEXS}_{\mathrm{it}-1}\right)$, percent of the school district's legislative districts held by Republicans (REPUBLICANS ${ }_{\mathrm{it}-1}$, REPUBLICANH $\mathrm{it}_{\mathrm{it}-1}$ ), years of legislative service $\left(\mathrm{YEARS}_{\mathrm{it}-1}, \mathrm{YEARH}_{\mathrm{it}-1}\right)$, and the number of new legislators in each school district $\left(\mathrm{NEWS}_{\mathrm{it}-1}, \mathrm{NEWH}_{\mathrm{it}-1}\right)$. Most leadership index variables had the expected positive signs, although only a few were significant. In particular, coefficients on the House leadership index in both 1992 regressions were positive and significant at the $1 \%$ level, while the coefficient on the Senate leadership index in the 1992 income regression was positive and significant at $10 \%$.

Coefficient estimates for the percent of school district held by Republicans variables were not significant. Years of legislative service was significant in only one equation. Years of service by senators in the 1992 income regression was negative and significant at $10 \%$.

The number of new legislators did not have a significant impact on the level of state aid in 1990 and 1992. However, the coefficient on the number of new representatives in the 1994 assessed value equation was positive and significant at $10 \%$. In addition, the coefficient estimates on the number of new senators in both 1996 equations were negative and significant at $1 \%$. No single agenda-setting variable consistently stands out as a significant factor. However, there was a 
strong relationship between state aid and leadership in the House in 1992, and also between state aid and new senators in 1996.

The per pupil number of representatives $\left(\mathrm{LTOTALH}_{\mathrm{it}-1}\right)$ and average daily membership ( $\left(\mathrm{LADM}_{\mathrm{it}-1}\right)$ were included to test the unequal representation hypothesis. In the 1990 regressions, coefficient estimates for these variables were not significant. In the 1992 income regression, the coefficient on the number of representatives had an unexpected negative sign, and was significantly different from zero at $10 \%$, while the coefficient on the average daily membership variable in the income and assessed value regressions had expected negative signs and were significant at 5\%. In the 1994 regressions, only the coefficient on the number of representatives variable was significant at ten percent, but had an unexpected negative sign. Finally, in the 1996 regressions, the coefficient estimates for the number of representatives and average daily membership variables were not significant. There appears to be evidence for the unequal representation hypothesis only in the writing of the 1992 school funding formula.

The final aspect we address is that of equalization of state aid among school districts. This was considered by including a measure of per capita income in the ith school district $\left(\mathrm{LINCOME}_{\mathrm{i} 87}\right)$, or of assessed property values $\left(\mathrm{LAV}_{\mathrm{it}-1}\right)$. Coefficient estimates for these variables in the 1990 and 1992 regressions were negative, as expected, and significantly different from zero at $1 \%$. In the 1994 income regression, the coefficient on per capita income was negative and significant at $1 \%$, but the coefficient on the assessed value variable was not significant. Finally, neither of these coefficient estimates was significant in the 1996 regression. Thus, there is evidence of equalization in 1990, 1992, and 1994, but not in 1996.

\section{SUMMARY AND CONCLUSIONS}

The distribution of state aid to schools is determined by legislatures. The way that legislatures form majority coalitions may affect which school districts benefit more, and which benefit less, from the chosen distribution formula. We test several hypotheses about coalition forming in legislatures using data on Indiana school finance for 1990, 1992, 1994, and 1996. State school aid per pupil received by each of Indiana's 294 school districts is regressed on school district and legislator characteristics.

We find no evidence for policy cycling in any of the four years considered. The previous session's aid distribution was a strong determinant of the current year's distribution in every year and specification tested. This result is consistent with past work on legislatures (Stratmann 1996; Mueller 1989). For Indiana, it may be that the Senate provided stability in coalition formation. It was strongly controlled by the Republicans throughout this period. Likewise, the Governor was a Democrat throughout this period. Or, perhaps experienced legislators see little benefit in fostering a culture of coalition switching, since this year's winners might be next year's losers.

Cycling can be avoided if legislative leaders set agendas. The school districts represented by such leaders likely would benefit from the adopted funding 
distribution. There is evidence that leaders set the agenda to the benefit of their school districts in 1992. A new majority coalition may have formed that year. It was the first year that the Democrats took the majority in the House, and was the first year in a generation that Democrats controlled both a legislative body and the governor's office. In 1992, school districts represented by House leaders and influential committee members did well relative to those without such representation. There is lesser evidence that Senate leaders did well by their districts, too. In only one other year, 1996, is there evidence that the identity of a district's representatives influenced its state aid. That year, districts represented by newly elected, first term Senators received less in aid than other districts. In 1996, the Senate took the major role in writing the formula (when the House "dropped the ball"). It appears that senators with experience in state aid coalition formation had the advantage.

School district boundaries do not match legislative district boundaries, and the number of public school children as a share of the population varies among districts. This means that some school districts are overrepresented, and some are underrepresented, relative to the size of their enrollment. In 1992, this unequal representation appears to have affected the school formula. School districts with smaller enrollments saw bigger aid increases, all else equal. A smaller district costs less to include in a majority coalition, because the added aid per pupil is less. Yet the small district's legislator contributes the same vote that a large district's legislator does. In years other than 1992, small districts did not appear to have this advantage.

Legislators may support funding equalization because of equity concerns. Or, equalization may arise because the median legislator has the power to redistribute funds from richer districts, or because of the threat of coalition-disrupting court cases. Measures of school district income and wealth are significant determinants of aid in 1990,1992, and 1994. Poorer districts increased their aid relative to richer districts in each of these years, which is evidence of equalization. There is no such evidence for 1996. After the 1993 formula was passed-the one that determined 1994's aid distribution - the court challenge to the state's formula was dropped. Could it be that legislators supported moves toward equalization only under pressure of the court case?

In most years, the Indiana school aid formula distribution appears to be stable. There is no policy cycling. A new coalition appears to have formed only in 1992, a year when a new party took power in the House, and served with a Governor of the same party. In that year, school districts represented by legislative leaders, and school districts with smaller enrollments, had the advantage. Over several years, increased funding equalization appears to have been a goal of legislators, but evidence for this trend disappears after school districts dropped a court challenge to the formula. 


\section{REFERENCES}

Advisory Commission on Intergovernmental Relations. The Structure of State Aid to Elementary and Secondary Education. M-175, December 1990.

Atlas, Cary M., Thomas W. Gilligan, Robert J. Hendershott, and Mark A. Zupan. "Slicing the Federal Government Net Spending Pie: Who Wins, Who Loses, and Why." American Economic Review 85 (June 1995), 624-629.

Baron, David P., and John Ferejohn. "Bargaining and Agenda Formation in Legislatures." American Economic Review 77 (May 1987), 303-309.

Brown, Patricia R., and Richard F. Elmore. "Analyzing the Impact of School Finance Reform." In N.H. Cambron-McCabe and A. Odden (eds.) The Changing Politics of School Finance. Third Annual Yearbook of the American Education Finance Association, 107-138. Cambridge, MA: Ballinger Publishing Co., 1982.

de Bartolome, Charles A.M. "What Determines State Aid to School Districts? A Positive Model of Foundation Aid as Redistribution." Journal of Policy Analysis and Management 16 (Winter 1997), 32-47.

Dougan, William R., and James M. Snyder, Jr. "Interest Group Politics Under Majority Rule." Journal of Public Economics 61 (July 1996), 49-71.

Evans, William N., Sheila E. Murray, and Robert M. Schwab. "Schoolhouses, Courthouses and Statehouses After Serrano." Journal of Policy Analysis and Management 16 (Winter 1997), 10-31.

Fuhrman, Susan. "State-Level Politics and School Financing." In N.H. CambronMcCabe and A. Odden (eds.) The Changing Politics of School Finance. Third Annual Yearbook of the American Education Finance Association, 53-70. Cambridge, MA: Ballinger Publishing Co., 1982.

Indiana Department of Education. Digest of Public School Finance in Indiana, 19992001 Biennium. Indianapolis, 1999.

Johnson, Carlyn E. School Funding Equity: An Implied Promise. School of Public and Environmental Affairs, Indiana University Policy Report, October 1993.

Johnson, Carlyn E., and Robert G. Lehnen. "Reforming Indiana's School Finance Formula, 1973-90: A Case of Unanticipated Outcomes." Journal of Education Finance 18 (Winter 1993), 264-280.

Kmenta, Jan. Elements of Econometrics. 2d ed. New York: Macmillan Publishing Company, 1986.

Levitt, Steven D., and James M. Snyder, Jr. "The Impact of Federal Spending on House Election Outcomes." The Journal of Political Economy 105 (February 1997), 30-53.

Meltzer, Allan H., and Scott F. Richard. "A Rational Theory of the Size of Government." The Journal of Political Economy 89 (October 1981), 914-927.

Mueller, Dennis C. Public Choice II. Cambridge, MA: Cambridge University Press, 1989.

(ed.) Perspectives on Public Choice: A Handbook. Cambridge: Cambridge University Press, 1996. 
Snyder, James M., Jr. "Comment on 'Interest, Central Leadership, and the Passage of TRA86.' " Journal of Policy Analysis and Management 12 (1993), 181-185.

Stratmann, Thomas. "Instability of Collective Decisions? Testing for Cyclical Majorities." Public Choice 88 (July 1996), 15-28.

Wong, Kenneth K. "State Reform in Education Finance: Territorial and Social Strategies." Publius: The Journal of Federalism 21 (Summer 1991), 125-142. 
